\title{
Hubungan Luar Negeri Provinsi Maluku dengan Selandia Baru dalam Mengembangkan Energi Terbarukan
}

\author{
Abdullah Randika Anwar \\ Windy Dermawan \\ RMT Nurhasan Affandi \\ Gilang Nur Alam \\ Universitas Padjadjaran
}

\begin{abstract}
Maluku Province is one of the regions that has the potential for renewable energy resources which are quite abundant, but they have not been utilized properly due to various obstacles and challenges in the region. In order to overcome the existing problems, Maluku Province has established foreign relations with the Government of New Zealand through the New Zealand Booking program-Maluku Access to Renewable Energy Support (NZMATES) starting from April 2018 to June 2023. This research aims to describe how the efforts taken by the Maluku Provincial Government and the New Zealand Government in developing renewable energy in the Maluku region. By using qualitative methods with data techniques through literature studies and internet-based document searches, this article argues that through the establishment of foreign relations between Maluku Province and New Zealand through the formation of NZMATES it can help and facilitate the process of developing renewable energy in the Maluku region. NZMATES can create a more competent work environment by engaging with several agencies with regional interests to participate in developing renewable energy in Maluku Province.
\end{abstract}

Keywords: Maluku province foreign relations; renewable energy; NZMATES

\begin{abstract}
Abstrak
Provinsi Maluku merupakan salah satu daerah yang memiliki potensi sumber daya energi terbarukan yang cukup melimpah, akan tetapi belum dimanfaatkan dengan baik karena berbagai hambatan dan tantangan yang ada di daerahnya. Demi mengatasi permasalahan yang ada, Provinsi Maluku menjalin hubungan luar negeri dengan Pemerintah Selandia Baru melalui pembentukan program New Zealand - Maluku Access to renewable Energy Support (NZMATES) yang dimulai pada April 2018 hingga Juni 2023. Riset ini memiliki tujuan untuk memaparkan mendeskripsikan bagaimana upaya yang ditempuh oleh Pemerintah Provinsi Maluku dan Pemerintah Selandia Baru dalam megembangkan energi terbarukan di daerah Maluku. Dengan menggunakan metode kualitatif dengan teknik pengumpulan data melalui studi pustaka dan penelusuran dokumen berbasis internet, tulisan ini berargumen bahwa melalui terjalinnya hubungan luar negeri antara Provinsi Maluku dengan Selandia Baru melalui terbentuknya NZMATES dapat membantu dan mempermudah proses pengembangan energi terbarukan di wilayah Maluku. NZMATES dapat menciptakan lingkungan kerja yang lebih berkompeten dengan memberi keterlibatan dengan beberapa lembaga berkepentingan daerah untuk ikut berpartisipasi dalam mengembangkan energi terbarukan di Provinsi Maluku.
\end{abstract}

Kata-kata kunci: hubungan luar negeri provinsi Maluku; energi terbarukan; NZMATES 


\section{Pendahuluan}

Hampir seluruh aktivitas yang kita lakukan selalu bergantung pada energi, mulai dari kebutuhan mendasar seperti penggunaan alat rumah tangga hingga penggerak mesin-mesin industri yang dapat berfungsi dengan adanya daya energi. Hal ini menyebabkan energi tidak dapat terlepas dari kehidupan manusia, Ketergantungan negara terhadap energi konvensional dapat mengakibatkan terjadinya kelangkaan energi konvensional dan meningkatnya kerusakan lingkungan (Cahyanto, 2014). Pada 2017, sumber energi terbarukan di Indonesia baru menyumbang sebesar $8 \%$ dari campuran energi primer nasional, sementara $92 \%$ lainnya masih dipenuhi oleh bahan bakar fosil. Tren yang sama dapat dilihat di sektor listrik Indonesia dimana pemanfaatan energi terbarukan hanya mencapai $12 \%$ pada 2017 sementara bahan bakar fosil tetap mendominasi sektor ini dengan menghasilkan $88 \%$ listrik. Penambahan kapasitas energi terbarukan dari tahun ke tahun ini telah menurun sejak 2013. Pada 2017, Indonesia hanya menambah 242 MW energi terbarukan, terendah sejak 2011. Investasi energi terbarukan di Indonesia adalah 1,3 miliar USD pada 2017, lalu mengalami penurunan sebesar $17 \%$ dibandingkan pada tahun sebelumnya, yaitu 1,57 miliar USD (Kementerian Energi dan Sumber Daya Mineral, 2017).

Indonesiatelahmenjalinberbagaikerjasamaluarnegeridalammengembangkan energi terbarukan. Salah satu negara yang bekerja sama dengan Indonesia dalam sektor pengembangan energi terbarukan adalah Selandia Baru. Hubungan bilateral antarkedua negara ini sudah berjalan selama 63 tahun lamanya, dan kini sedang berkembang di Maluku (Amin, 2020). Untuk memperingati terjalinnya hubungan diplomatik selama 60 tahun ini, Presiden Joko Widodo bersama Perdana Menteri Jacinda Ardern menyepakati beberapa hubungan kerjasama (Kementerian Luar Negeri RI, 2018). Berdasarkan New Zealand - Indonesia Joint Commitment for Developing untuk tahun 2017 hingga 2022, sektor energi terbarukan mendapatkan alokasi dana terbesar dalam program kerjasama Selandia Baru dengan Indonesia. Selandia Baru menyediakan dana sebesar New Zealand Dollar (NZD) 30 juta untuk program pelatihan dan pemberdayaan sumber daya manusia mengenai akses energi terbarukan yang baik di masa mendatang (Kusumawanti, 2020). Dari total dana tersebut, sebesar NZD 10 juta dialokasikan bagi program pengembangan energi terbarukan di Provinsi Maluku dengan sasarannya di wilayah-wilayah kepulauan Provinsi Maluku (Ririen, 2018).

Provinsi Maluku adalah salah satu provinsi terpencil di Indonesia yang memiliki sekitar 1,7 juta penduduk. Menurut Badan Pusat Statistik (BPS), Maluku adalah provinsi yang memiliki penduduk paling bahagia kedua di Indonesia dan merupakan rumah bagi salah satu populasi yang paling beragam secara budaya. Produksi perikanan dan pertanian di Maluku adalah salah satu keunggulan kompetitif ekonomi utama provinsi ini, selain itu Maluku juga termasuk produsen dari sebagian besar pala dunia. Maluku adalah tempat yang ramai dan beragam, tempat budaya Asia Tenggara dan Melanesia bertemu. Provinsi ini juga menawarkan arena penyelaman kelas dunia, pantai yang spektakuler, lingkungan alami yang kaya keanekaragaman hayati, dan penduduk yang ramah. Namun demikian, akses ke pasar merupakan tantangan utama bagi hampir semua wilayah Maluku (NZMATES, 2019).

Rasio elektrifikasi (RE) di Maluku telah meningkat dalam beberapa tahun terakhir, meningkat dari 70,8\% pada tahun 2011 menjadi 92\% di tahun 2019, namun rasio elektrifikasinya masih di bawah rata-rata nasional yaitu 99\%. Di Maluku dan Maluku Utara, lebih dari 99\% listrik yang dihasilkan masih menggunakan diesel, dengan hanya beberapa mini-grid tenaga surya berskala kecil (Mayaut, 2019). Ketergantungan terhadap bahan bakar fosil ini membuat pembangkit listrik 
menjadi tidak stabil, mahal, dan belum lagi sifatnya yang tidak ramah lingkungan. Maka dari itu ketergantungan ini tidak seterusnya dapat diandalkan. Akibatnya, masih terdapat desa yang tidak mendapatkan listrik. Kondisi ini menunjukkan bahwa keseluruhan beban pada pasokan masih menggunakan power diesel yang dimiliki oleh PT. PLN atau disewa oleh perusahaan swasta dan untuk pulau-pulau atau desa-desa yang tidak terjangkau oleh PLN, kebutuhan listrik harus dikejar secara mandiri dan sebagian oleh penduduk setempat (Anchank, 2020). Salah satu solusi untuk mengatasi masalah ini adalah dengan memanfaatkan teknologi energi terbarukan, yang hingga saat ini belum digunakan secara optimal terutama energi matahari dan angin (Hariyanti, 2016).

Keterbatasan akses terhadap energi diidentifikasikan sebagai tantangan utama dalam mengatasi kesenjangan di Maluku, baik dari sisi sosial ataupun dalam hal kapasitas produksi. Akses terhadap energi berkorelasi dengan meningkatnya kesejahteraan keluarga, layanan sosial dan masyarakat, serta dapat mengoptimalkan kegiatan ekonomi di Maluku. Energi terbarukan dapat memberikan peluang untuk mencapai hal-hal tersebut, dan membantu Indonesia memenuhi target sasaran dalam mengatasi perubahan iklim. Berdasarkan sejumlah potensi yang perlu dikembangkan di Provinsi Maluku dan tantangan bagi pengembangannya sebagaimana paparan di atas, Pemerintah Provinsi Maluku dan Duta Besar Selandia Baru untuk Indonesia meluncurkan program yang bernama "New Zealand - Maluku Access to renewable Energy Support" (NZMATES). Hal ini dilakukan pula demi memperingati terjalinnya hubungan bilateral antara Indonesia dengan Selandia Baru yang ke 60 tahun, ditandai dengan penandatangan Momerandum of Understanding (MoU) antara kedua belah pihak di Kantor Gubernur Maluku (Ririen, 2018).

Terdapat sejumlah studi terdahulu yang memiliki keterkaitan dengan riset yang dilakukan. Studi dari Coyle dan Simmons (2014), Manieniyan dkk (2009), Fitra dan Asirin (2018), dan Aftab (2014) membahas bagaimana penyebab, konsekuensi dan kemungkinan perbaikan atas terjadinya krisis energi. Keempat riset tersebut membahas kelangkaan energi yang terjadi dalam skala global hingga nasional akibat permintaan dan konsumsi energi yang terus meningkat melampaui pasokannya. Studi yang dilakukan oleh Kholiq (2015), Puspitarini (2015), Lubis (2007), Schwanitz dkk (2017), Heyko dkk (2017) menemukan bahwa potensi dan manfaat dari energi terbarukan bagi kepentingan dan kebutuhan insani. Terdapat pula studi terdahulu mengenai kiprah aktor subnegara sebagai dampak dari globalisasi dan perkembangan teknologi yang telah memperluas aktor hubungan internasional, diantaranya Pluijm dan Melissen (2007), Cunha dan Rei (2011), Thontowi (2009), Harakan (2018), Sergunin dan Joenniemi (2014). Berdasarkan studi-studi terdahulu di atas, studi mengenai kiprah aktor subnegara dalam hubungan luar negerinya dengan aktor negara di dalam pengembangan sumber energi terbarukan masih terbatas kajiannya. Studi mengenai hirauan aktor subnegara terhadap pengembangan sumber energi terbarukan melalui hubungan luar negeri dengan aktor lain mampu mengisi kekosongan diantara studi-studi terdahulu di atas.

Tulisan ini hendak mempertanyakan mengenai bagaimana hubungan luar negeri Provinsi Maluku dengan Selandia Baru yang dicapai berdasarkan ikhtiarnya mengenai pengembangan energi terbarukan. Berdasarkan hal tersebut, tulisan ini memaparkan mengenai upaya yang ditempuh oleh Pemerintah Provinsi Maluku dan Pemerintah Selandia Baru dalam mengembangkan energi terbarukan di daerah Maluku melalui program NZMATES. Tulisan ini juga sekaligus ingin menyoroti mengenai kiprah dan keterlibatan aktor subnegara di Indonesia dalam kapasitasnya melakukan hubungan luar negeri yang dapat membantu pemerintah 
pusat di dalam konteks pembangunan nasional. Pengembangan energi terbarukan diharapkan dapat membawa pada implikasi pengembangan sumber-sumber daerah di Provinsi Maluku sehingga dapat mendukung bagi pembangunan daerah.

\section{Transgovernmentalisme: Sebuah Kerangka Konseptual}

Ilmuwan politik Robert Koehane dan Joseph S. Nye mendefinisikan transgovermentalisme sebagai suatu hubungan interaksi antara sub-unit dari pemerintah yang tidak dikendalikan atau dipandu oleh kebijakan kabinet atau kepala eksekutif dari pemerintah tersebut. Hubungan transgovermental memiliki perbedaan dari hubungan inter-state. Hubungan transgovermental hanya berfokus terhadap interaksi antar sub-state actor sedangkan hubungan inter-state menekankan interaksi antar negara. Selanjutnya hubungan transgovermental mengasumsikan bahwa sub-state actor dapat bertindak secara otonom dalam politik internasional sedangkan pada hubungan inter-state mengasumsikan bahwa negara bertindak sebagai satu aktor kesatuan (Keohane \& Nye, 1974). Aktor sub-negara (sub-state actor) secara tradisional didefinisikan sebagai "low policy", seperti isu-isu terkait masalah lingkungan, kebudayaan, investasi, pendidikan, dan lainya. Ini kontras dengan "high policy" yang diwakili oleh agenda keamanan diplomatik dan militer dari pemerintah pusat. Dengan kata lain, hubungan luar negeri daerah merepresentasikan proyeksi di luar negeri dari kompetensi domestik pemerintah daerah, yang sebagian besar terkonsentrasi pada isu-isu "low policy" tersebut (Tavarez, 2016). Menurut Keohane dan Nye (1973), politik dunia bukanlah sistem hubungan politik antar negara melainkan sebuah interaksi politik antara "significant actors" yang memiliki karakteristik seperti otonomi, kontrol atas sumber daya substansial yang relevan dengan isu di wilayah tertentu dan partisipasinya dalam hubungan politik lintas negara. Pemerintah daerah, bersama dengan berbagai organisasi internasional dan transnasional juga terlibat dalam daftar significant actors tersebut.

Keohane dan Nye juga membedakan antara dua jenis utama hubungan transgovermental, yaitu policy coordination dan coalition building. Transgovernmental policy coordination mengacu pada aktivitas yang dirancang untuk memfasilitasi kelancaran implementasi atau penyesuaian kebijakan, tanpa adanya arahan dari kebijakan yang lebih tinggi. Sedangkan transgovernmental coalition building terjadi ketika sub-unit pemerintah membangun kerjasama atau koalisi dengan lembaga pemerintah lain karena adanya ketertarikan atau kepentingan dengan sub-unit pemerintah dari negara lain (Keohane \& Nye, 1974). Pada hubungan luar negeri Selandia Baru membentuk sebuah kerjasama atau koalisi dengan lembaga pemerintah Maluku dalam mengembangkan inovasi pemberdayaan sumber energi terbarukan yang ada di Maluku. Sementara itu, Slaughter (1997) mendefinisikan hubungan transgovermental sebagai suatu pola hubungan yang teratur yang dilakukan antara unit-unit pemerintah dan bekerja melintasi perbatasan negara. Dia membedakan tiga tipehubungan transgovermental. Pertama, transgovernmental networks dalam organisasi internasional. Kedua transgovernmental networks dalam kerangka kerja yang telah dinegosiasikan dan disepakati setidaknya oleh kepala pemerintahannya. Terakhir spontaneous transgovernmental networks, yaitu jaringan yang tidak memerlukan interstate agreement dan dapat memformalkan diri mereka sendiri sebagai bagian dari hubungan transgovermental.

Transgovermentalisme memberikan berbagai alasan untuk meningkatkan hubungan antar pemerintah, diantaranya seperti peningkatan saling ketergantungan regulasi, peningkatan tingkat perdagangan, peningkatan pelembagaan politik, dan perkembangan teknologi. Hal tersebut mendukung 
hubungan transgovermental dalam memfasilitasi pengaturan dari berbagai bidang masalah atau dalam memenuhi kebutuhan atau tujuannya. Setelah itu, apabila suatu daerah telah mendapat status otonom, maka hubungan transgovermental akan lebih sering terjadi (Whytock, 2005). Daerah dengan status otonom biasanya lebih suka bekerja sama antar pemerintah daerah lintas batas dibandingkan bekerja sama antar negara karena dalam jaringan antar pemerintah, para pemerintah daerah otonom dapat berinteraksi secara langsung dengan rekan mereka tanpa pengawasan dari pemerintah pusat atau kepala negara (Whytock, 2005). Menurut Slaughter transgovernmental network juga dapat berkontribusi terhadap tatanan dunia dengan mengembangkan kualitas, sifat, serta ruang lingkup internasional (Slaughter, 1997).

Literatur transgovernmentalisme memberikan beberapa alasan dalam peningkatan interikasi antara pemerintah secara umum, seperti ketergantungan regulasi, proliferasi badan pengatur di dalam negara, peningkatan tingkat perdagangan demi harmonisasi peraturan untuk mengatasi permasalahan nontarif, peningkatan kelembagaan politik dunia, dan perkembangan atau perubahan teknologi yang telah membuat transgovernmental lebih dibutuhkan (Keohane \& Nye, 1974). Perubahan teknologi, perkembangan industry, perluasan regulasi domestik, dan globalisasi telah mengembangkan transgovernmental network. Konsep transgovermentalisme akan membantu periset dalam memberikan pemahaman terkait kegiatan yang dilakukan oleh Provinsi Maluku dalam menjalin hubungan luar negeri dengan Selandia Baru. Terdapat interaksi yang dilakukan Pemerintahan Provinsi Maluku sebagai sub-state actor dalam menjalani hubungan luar negeri daerah dengan membentuk program kerja NZMATES bersama Selandia Baru untuk mengembangkan energi terbarukan serta menangani isuisu terkait energi di wilayah Maluku. Transgovernmentalisme menjadi landasan atas terjalinnya interkasi antara sub-state actor dengan berbagai aktor lain. Dengan perkembangintan teknologi dan globalisasi, kini hubungan luar negeri tidak hanya melibatkan state-actor melainkan menjadi interaksi politik antara significant actors, yaitu aktor yang memiliki karakteristik seperti kebijakan atau regulasi, otonomi, dan kontrol atas sumber daya substansial yang relevan dengan isu di wilayah tertentu dan terlibat dalam hubungan politik lintas negara demi mencapai masing-masing tujuannya. Dalam riset ini, kami berusaha meneliti hubungan luar negeri daerah yang dilakukan oleh sub-state actor yaitu Maluku dengan Selandia Baru dan beberapa MNCs yang terlibat melalui sebuah kebijakan yang bernama NZMATES dalam mengembangkan energi terbarukan di wilayah Maluku demi memenuhi bauran energi nasional Indonesia.

Konsep Keohane dan Nye semakin diperkuat oleh fakta bahwa pembagian yang dulunya sangat penting antara politik "tinggi" dan "rendah" telah memudar. Asumsi bahwa "high politic", seperti hubungan keamanan suatu negara dengan negara lain dalam sistem internasional, bersifat otonom berbeda dari "low politic", yang merupakan tekanan sosial, ekonomi, dan politik domestic (Tavarez, 2016). Sejumlah isu-isu kebijakan rendah, seperti perubahan iklim, pembangunan berkelanjutan atau pendidikan, kini telah menjadi bagian penting dari hubungan luar negeri (Barnet, 1990). Akibatnya, suatu daerah, sebagai entitas yang seharihari menghadapi masalah tersebut, secara alamiah cenderung mengembangkan berbagai hubungan luar negeri untuk mengatasi masalah domestiknya. Perkembangan teknologi dan perindustrian kini telah memunculkan berbagai macam isu kompleks yang harus dihadapi negara. Selain itu juga pemenuhan kebutuhan manusia yang terus meningkat. Hal ini menyebabkan pemerintah pusat kewalahan dalam menghadapi masalah-masalah yang terjadi baik permasalahan di dalam negeri maupun luar negeri sehingga berkurangnya perhatian dari 
pemerintah pusat terhadap pemerintah daerah. Maka dari itu banyak wilayahwilayah seperti provinsi maupun kota dari sebuah negara yang melakukan diplomasi ke daerah di negara lain.

Di era globalisasi ini, sebagian besar negara di dunia mulai mengkhawatirkan isu-isu low politic yang semakin mengancam kesejahteraan masyarakat. Isu tersebut telah menyebabkan gesekan aktor hubungan internasional. Sebelum era globalisasi, negara memiliki kekuatan yang sangat dominan, namun dengan kebangkitan aktor-aktor baru, seperti pemerintah daerah, lembaga swadaya masyarakat, dan perusahaan multinasional, menciptakan suasana baru dalam jalur diplomasi. Saat ini diplomasi tidak eksklusif untuk hubungan government to government, tetapi meluas mencakup hubungan government to non government, non government to non government, government to people, dan people to people relation (Barnet, 1990). Kusnetsov (2015), berpendapat bahwa terdapat dua faktor yang menyebabkan terjalinnya hubungan luar negeri daerah, yaitu faktor eksternal dan faktor internal. Faktor eksternal antara lain adalah globalisasi, regionalisasi, domestikasi kebijakan luar negeri, dan internasionalisasi kebijakan domestik. Sedangkan faktor internal dipengaruhi oleh desentralisasi, federalisasi, efektivitas pemerintah pusat dalam hubungan luar negeri, pengaruh pemimpin daerah atau partai politik, dan letak geografis yang berkaitan dengan perbatasan wilayah (Kuznetsov, 2015).

Munculnya daerah sebagai aktor transnasional dapat dijelaskan sebagai hasil dari penguatan identitas sub-negara. Ini merupakan konsekuensi dari terjadinya perubahan besar dalam sistem internasional, dengan berkurangnya peran hubungan antarnegara, memudarnya pembagian antara politik tinggi dan politik rendah, serta demokratisasi dan modernisasi yang memungkinkan untuk menghubungkan negara dengan aktor sub-negara ataupun aktor non-negara. Pada masa globalisasi ini, pemerintah daerah mulai memiliki kewenangan yang kuat dalam ruang lingkup internasional. Pemerintah daerah biasanya mengutamakan otoritasnya berdasarkan masalah-masalah yang terjadi di daerah seperti kebudayaan, penanaman modal atau investasi, turisme atau pariwisata, pendidikan, dan berbagai isu lain yang tergolong penting seperti persoalan pembangunan yang meluas. Dengan adanya kemajuan teknologi dan komunikasi telah mempermudah pemerintah daerah dalam melakukan hubungan luar negeri untuk memenuhi kebutuhan domestiknya. Selain itu, hubungan luar negeri daerah ini juga dapat dilihat sebagai salah satu upaya pemerintah daerah untuk mempromosikan identitas daerahnya.

\section{Kebijakan Energi Nasional Indonesia}

Untuk mengatasi permasalahan pada sektor energi di Indonesia atas dasar Undang-Undang Nomor 30 tahun 2007 tentang Energi, pemerintah pusat bersama DPR-RI mengamanatkan penyusunan Kebijakan Energi Nasional (KEN) yang jelas dan terukur sebagai pedoman dalam pengelolaan energi nasional dengan prinsip berkeadilan, berkelanjutan, dan berwawasan lingkungan guna terciptanya kemandirian energi dan ketahanan energi nasional. Kebijakan Energi Nasional (KEN) dirancang dan dirumuskan oleh Dewan Energi Nasional (DEN) dan melalui persetujuan DPR-RI, Kebijakan Energi Nasional (KEN) ditetapkan dalam Peraturan Pemerintah Nomor 79 tahun 2014 tentang Kebijakan Energi Nasional (Pemerintah Indonesia, 2014). KEN menargetkan pemanfaatan energi terbarukan setidaknya mencapai $23 \%$ dari bauran energi primer nasional pada tahun 2025 dan mencapai 31\% pada tahun 2050 (Dewan Energi Nasional, 2014). Sayangnya, pengembangan energi terbarukan di Indonesia sangat lambat, hingga tahun 2019 peran energi terbarukan baru mencapai 9,15\% dari total konsumsi energi 
nasional (Dewan Energi Nasional, 2020). Hal ini disebabkan oleh berbagai faktor, salah satunya adalah kesenjangan kebijakan dan regulasi di Indonesia. UndangUndang Nomor 30 tahun 2007 juga mengamanatkan penyusunan Rencana Umum Energi Nasional (RUEN) dan Rencana Umum Energi Daerah (RUED) sampai dengan 2050 demi mendukung implementasi KEN. Pada Peraturan Presiden (Prepres) Nomor 22 Tahun 2017, RUEN menjadi kebijakan dan penjabaran rencana pelaksanaan Kebijakan Energi Nasional pemerintah pusat yang bersifat lintas sektor untuk mewujudkan kemandirian dan ketahanan energi dalam mendukung pembangunan nasional secara berkelanjutan lalu RUEN disahkan dan ditandatangani oleh Presiden Jokowi pada tanggal 2 Maret 2017 (Pemerintah Indonesia, 2017).

Dalam mendukung pembangunan dan pengembangan di sektor ketenagalistrikan maka pemerintah menyusun Rencana Umum Ketenagalistrikan Nasional (RUKN) yang merupakan rencana pengembangan sistem penyediaan tenaga listrik yang disusun oleh pemerintah pusat yang meliputi bidang pembangkitan, transmisi, dan distribusi tenaga listrik yang diperlukan untuk memenuhi kebutuhan tenaga listrik nasional. RUKN disusun oleh Menteri berdasarkan KEN lalu ditetapkan oleh Menteri setelah berkonsultasi dengan DPR-RI. Selanjutnya untuk daerah terdapat Rencana Umum Ketenagalistrikan Daerah (RUKD) yang disusun oleh Pemda yang berdasarkan dan berpedoman pada RUKN dan ditetapkan oleh Gubernur daerah setempat setelah berkonsultasi dengan Dewan Perwakilan Rakyat Daerah (DPRD) (Kementerian ESDM, 2016). Kebijakan berikutnya adalah Rencana Usaha Penyediaan Tenaga Listrik (RUPTL) menjadi dasar pelaksanaan usaha penyediaan tenaga listrik untuk kepentingan umum. RUPTL disusun oleh badan usaha yang memiliki wilayah usaha dengan memperhatikan Rencana Usaha Ketenagalistrikan. RUPTL disahkan oleh Menteri dan Gubernur sesuai kewenangannya. Dalam Peraturan Pemerintah No. 14 Tahun 2012 dijelaskan bahwa RUPTL adalah sebuah rencana pengembangan tenaga listrik dan kebutuhan investasi. Rencana ini berlaku selama sepuluh tahun dan dapat ditinjau ulang setiap tahunnya. Pemohon Izin Usaha Penyediaan Tenaga Listrik yang ingin mengajukan untuk usaha distribusi, usaha penjualan, atau usaha penyediaan tenaga listrik yang terintegrasi wajib menyusun RUPTL. RUPTL ini selanjutnya disahkan oleh Menteri atau Gubernur sesuai dengan kewenangan mengeluarkan Surat Izin Usaha Penyediaan Tenaga Listrik (IUPTL) (Pemerintah Indonesia, 2014).

RUPTL digunakan oleh para pemegang IUPTL sebagai pedoman pelaksanaan kegiatan usaha penyediaan tenaga listrik. RUPTLini dievaluasi secara berkala setiap satu tahun oleh pemegang izin tersebut. Apabila dari hasil evaluasi, pemegang IUPTL melihat perlunya ada perubahan terhadap RUPTL, maka pemegang IUPTL dapat mengajukan revisi rencana usaha penyediaan tenaga listrik kepada menteri atau gubernur untuk memperoleh pengesahan. Tidak hanya itu, dalam hal tertentu, menteri atau gubernur sesuai kewenangannya dapat memerintahkan kepada pemegang izin usaha tersebut untuk mengubah RUPTL.

\section{Kebijakan Energi Terbarukan di Provinsi Maluku dan Selandia Baru}

Rencana Pembangunan Jangka Menengah Nasional (RPJMN) 2015-2019 fokus pada pembangunan ekonomi dan infrastruktur dasar untuk masyarakat. Selaras dengan RPJMN, Rencana Pembangunan Jangka Menengah Daerah (RPJMD) Provinsi Maluku menyoroti perlunya ketersediaan listrik untuk mempercepat investasi. Namun, pemerintah daerah mengalami kesulitan dalam membiayai pengembangan jaringan listrik untuk 294 dari 1.340 pulau di wilayah Maluku. Kapasitas pembangkit listrik Provinsi Maluku adalah 268,97 MW berdasarkan 
angka tahun 2018, dimana pembangkit listrik diesel menyediakan 206,56 MW dan pembangkit listrik turbin gas sekitar $60 \mathrm{MW}$ (Sekretariat Jenderal Ketenagalistrikan, 2018). Sejak tahun 1970, pengembangan pembangkit listrik di Provinsi Maluku masih sangat bergantung pada tenaga diesel dikarenakan banyaknya daerah pesisir yang terletak di wilayah kepulauan sehingga sulit dijangkau oleh listrik.

Perkembangan Rencana Umum Energi Daerah (RUED) Provinsi Maluku di tahun 2020 tercatat masih berada pada tahapan belum memfinalisasi dokumen, namun sudah berada pada tahapan peneyusunan dan perancangan Naskah Akademis dan Rancangan Peraturan Daerah (Ranperda). Setelah itu, berdasarkan Rencana Usaha Penyediaan Tenaga Listrik (RUPTL) 2019-2028, PLN akan meningkatkan rasio elektrifikasi di Provinsi Maluku pada tahun 2028 menjadi 456,654 MW. Perencanaan ini akan terfokus pada pengembangan pembangkit listrik berbasis energi terbarukan yaitu dengan pembangkit listrik tenaga air sebesar 66 MW, pembangkit listrik tenaga bioenergi sebesar $46 \mathrm{MW}$, dan minihidro sebesar 18,6 MW. Sedangkan untuk pembangkit listrik berbasis energi konvensional akan mengembangkan turbin gas sebesar $185 \mathrm{MW}$, batubara sebesar $80 \mathrm{MW}$, dan gas sebesar $50 \mathrm{MW}$.

Selandia Baru dan Indonesia memiliki forum konsultasi bilateral yang dilakukan secara rutin melalui Joint Ministerial Comission (JMC). JMC antara kedua negara ini pertama diadakan di Jakarta pada bulan Mei tahun 2007, kemudian JMC kedua diselenggarakan pada bulan Agustus 2009 di Wellington, Selandia Baru. JMC adalah forum utama diskusi antara Selandia Baru dengan Indonesia yang dipimpin oleh para menteri luar negeri. Pertemuan ini membahas bagaimana kerjasama antara kedua negara yang diharapkan dapat terus memperkuat hubungan antara Selandia Baru dengan Indonesia, baik pada tataran pemerintah maupun masyarakat (Kementerian Luar Negeri RI, 2018). Pada 29 Juli 2020, Menteri Luar Negeri Selandia Baru, Rt Hon Winston Peters dan Menteri Luar Negeri Republik Indonesia, Retno Marsudi bertemu secara virtual dalam rangka Joint Ministerial Commission (JMC) ke-9 antara Selandia Baru dan Indonesia. Sebagai Mitra Komprehensif, Selandia Baru dan Indonesia menegaskan kembali pentingnya hubungan dan persahabatan yang kuat, kepercayaan, dan niat baik bersama yang telah mendukung lebih dari 60 tahun hubungan diplomatic antara Selandia Baru dan Indonesia. Pada pertemuan tersebut, para Menteri mengadopsi Rencana Aksi Lima Tahun untuk mendorong kerja sama di bawah Kemitraan Komprehensif (New Zealand Ministry of Foreign Affairs and Trade, 2020). Terdapat 9 kategori perencanaan dalam Rencana Aksi Kemitraan Komprehensif antara Indonesia dan Selandia Baru untuk Periode 2020-2024, yaitu: cementing and expanding our "friends for good" ties; enhancing trade and economic partnership; renewable energy and environment cooperation; education, tourism, science, technology and innovation, and people-to-people cooperation; development cooperation; defence, security,cyber and maritime cooperation; regional and multilateral agenda; funding; dan review mechanism.

Untuk kategori "renewable energy and environment cooperations," program bantuan Selandia Baru (New Zealand Aid Partnership) telah menyediakan dana sebesar NZ\$ 30 juta untuk pelatihan dan bantuan teknis dalam mengembangkan energi terbarukan di Indonesia. Selandia Baru juga bekerja untuk mendukung pengembangan proyek energi terbarukan dan peningkatan akses energi di Provinsi Maluku. Selain itu, Selandia Baru juga terus berupaya untuk menarik lebih banyak 
pelajar Indonesia untuk belajar di negaranya, diketahui sebanyak 1.248 pelajar dari Indonesia mengambil program pendidikan di Selandia Baru pada tahun 2018. Perjanjian tentang Kerjasama Pendidikan sudah ada sejak tahun 2011 guna mendorong hubungan antara otoritas lembaga pendidikan dan penyelenggara pendidikan tinggi di setiap negara. Delapan universitas di Selandia Baru dan beberapa penyedia pelatihan independen memiliki hubungan langsung dengan berbagai universitas di Indonesia dan pemerintah provinsi yang menawarkan pelatihan pada bidang khusus. Di bawah Program Bantuan Selandia Baru untuk Indonesia, terdapat hingga 60 beasiswa disediakan untuk program studi pasca sarjana untuk setiap tahunnya bagi pelajar dari Indonesia (New Zealand Ministry of Foreign Affairs and Trade, 2020).

\section{Perkembangan Energi Terbarukan di Provinsi Maluku}

Provinsi Maluku memiliki potensi dalam memanfaatkan sumber energi terbarukan sebagai pembangkit listrik di wilayahnya, namun pengembangan pembangkit listrik berbasis energi terbarukan di Maluku masih terbatas. Sumber energi Provinsi Maluku yang berasal dari energi terbarukan baru mencapai 2,41 Megawatt (MW). Dengan total dari pembangkit listrik hybrid sebesar 0,45 MW; pembangkit listrik tenaga surya sebesar 1,92 MW; dan pembangkit listrik tenaga air sebesar 0,04 MW (Ditjen EBTKE, 2020). Pembangkit listrik tenaga surya di Provinsi Maluku telah dipasang oleh Kementerian Energi dan Sumber Daya Mineral; Kementerian Kelautan dan Perikanan; dan Kementerian Desa, Pembangunan Daerah Tertinggal, dan Transmigrasi. Total kapasitas dari pembangkit listrik berbasis energi terbarukan yang telah terpasang di Provinsi Maluku hingga saat ini masih kurang dari 5\% yang masih beroperasi (Fitrina \& Kurniawan, 2020). Berdasarkan RUPTL 2019-2028 dari Perusahaan Listrik Negara (PLN), PLN akan meningkatkan rasio elektrifikasi di Provinsi Maluku pada tahun 2028 menjadi 456,654 MW. Perencanaan ini akan terfokus pada pengembangan pembangkit listrik berbasis energi terbarukan yaitu dengan pembangkit listrik tenaga air sebesar $66 \mathrm{MW}$, pembangkit listrik tenaga bioenergi sebesar $46 \mathrm{MW}$, dan minihidro sebesar 18,6 MW. Sedangkan untuk pembangkit listrik berbasis energi konvensional akan mengembangkan turbin gas sebesar $185 \mathrm{MW}$, batubara sebesar $80 \mathrm{MW}$, dan gas sebesar $50 \mathrm{MW}$.

Akan tetapi, terdapat beberapa hambatan dalam proses pengembangan energi terbarukan di wilayah Maluku, akses terhadap energi menjadi faktor utama dalam mendorong pembangunan ekonomi dan menciptakan kesejahteraan bagi masyarakat. Pada tahun 2011, Provinsi Maluku memiliki tingkat kelistrikan terendah keempat di Indonesia, akan tetapi tingkat kelistrikan tersebut telah banyak mengalami peningkatan dalam beberapa tahun terakhir ini. Rasio elektrifikasi Provinsi Maluku pada tahun 2011 sebesar 70,80\% dan meningkat menjadi 91,25\% di tahun 2019. Terlepas dari elektrifikasi on-grid milik PLN, elektrifikasi off-grid juga memiliki peran penting dalam meningkatkan akses masyarakat terhadap energi. Selain itu karena kondisi geografis, beberapa daerah di Provinsi Maluku masih memiliki rasio elektrifikasi yang rendah seperti daerah-daerah kepulauan yang masih sulit untuk mendapatkan akses listrik (NZMATES , 2020). Maka dari itu, energi tebarukan berpotensi dan dapat menjadi peluang untuk mengatasi tantangan-tantangan ini serta dapat membantu dalam meningkatkan rasio elektrifikasi di daerah-daerah kepulauan Provinsi Maluku.

Melalui riset yang telah dilakukan NZMATES, Kementerian Energi dan Sumber Daya Mineral (ESDM) telah memasang Pembangkit Listrik Tenaga Surya (PLTS) di berbagai daerah di Provinsi Maluku. Terdapat sekitar 2,41 MW dari 
total kapasitas pembangkit listrik energi terbarukan di Provinsi Maluku. Saat ini terdapat 10 PLTS yang sudah dipasang oleh PLN dengan total kapasitas sebesar 1,11 MWp, 26 pembangkit listrik tenaga surya, dan 1 pembangkit listrik tenaga mikrohidro dengan kapasitas sebesar 0,035 MW. Terdapat pula pembangkit listrik dengan kapasitas yang lebih kecil dari bantuan kementerian lain di beberapa lokasi yang tersebar di wilayah Provinsi Maluku. Pembangkit listrik tenaga surya yang dibangun oleh PLN dapat berfungsi secara optimal selama 5 hingga 7 tahun dan saat ini statusnya sedang menunggu konfirmasi untuk diperbarui kembali. Pembangkit listrik yang telah terpasang oleh Kementerian ESDM telah diserahkan kepada pemerintah desa atau kecamatan untuk pemanfaatan, pemeliharaan, dan pengoperasian (NZMATES, 2020). Kapasitas pembangkit listrik di Provinsi Maluku pada 2028 diharapkan dapat mencapai angka 457,65 MW. Apabila menggunakan faktor perbandingan berbagai jenis energi dari RUKN, maka diproyeksikan jumlah tenaga teknis yang dibutuhkan dalam proses pengembangannya. Untuk mendukung pengembangan sektor ketenagalistrikan diperkirakan akan dibutuhkan sekitar 1.147 tenaga kerja professional yang telah bersertifikat. Selanjutnya permintaan atas teknologi bioenergi yang menjadi permintaan tertinggi dengan jumlah kebutuhan yang diproyeksikan sebesar 391 tenaga kerja. Diikuti dengan turbin gas yang membutuhkan 386 tenaga kerja; tenaga air dan minihidro yang membutuhkan sekitar 219 tenaga kerja; serta tenaga surya yang membutuhkan sekitar 49 orang tenaga kerja.

Apabila meninjau studi dari Greenpeace, jumlah total seluruh pekerja di Provinsi Maluku diperkirakan mencapai sekitar 3.503 full-time equivalent (FTE). Jumlah ini didominasi dengan energi terbarukan yang hampir mencapai 1.940 FTE sedangkan untuk energi konvensional sebesar 1.550 FTE. Pada pembangkit listrik berbasis fosil dan batubara membutuhkan tenaga kerja yaitu sejumlah 904 FTE. Selanjutnya untuk pembangkit listrik berbasis non-fosil, bioenergi memiliki jumlah tenaga kerja paling tinggi yaitu sebesar 864 FTE (Teske, et al., 2013). Dalam skenario ini pada tahapan konstruksi atau instalasi merupakan tahapan yang paling banyak membutuhkan tenaga kerja. Dalam mengembangkan jaringan transmisi dan gardu induk di Provinsi Maluku akan membutuhkan sekitar 144 tenaga kerja untuk mendukung layangan pengoperasian serta pemeliharaan. Dalam RUPTL 2019-2028, PLN berencana untuk memperluas jaringan transmisi sekitar $643 \mathrm{kms}$ untuk tegangan $70 \mathrm{kV}$ dan $150 \mathrm{kV}$ dimana diperlukan sekitar 40 tenaga kerja. Sedangkan untuk gardu induk diperkirakan akan membutuhkan tenaga kerja sebanyak 104 orang (Teske, et al., 2013).

Kementerian Tenaga Kerja di Ambon menyediakan Balai Latihan Kerja (BLK) untuk wilayah Provinsi Maluku yang berada di Passo, Kecamatan Baguala. BLK Ambon ini memberikan pelatihan tentang kelistrikan, konstruksi, dan geologi. Pelatihan yang diberikan BLK bersifat gratis dan terbuka untuk umum tanpa adanya persyaratan khusus. BLK dapat menampung hingga seribu peserta dan proses pelatihan disini memakan waktu satu bulan dengan 16 peserta pada setiap kelasnya (Fitrina \& Kurniawan, 2020). Di Provinsi Maluku juga terdapat dua Lembaga Sertifikasi Profesi (LSP) untuk sektor energi. Pertama LSP yang berada di BLK Ambon yang didukung oleh 17 asesor dari Provinsi Maluku. LSP ini memberikan sertifikasi untuk instalasi dan konstruksi ketenagalistrikan. Berikutnya LSP Politeknik Negeri yang juga berdada di Ambon. LSP Politeknik Negeri ini memberikan sertifikasi kompetensi di bidang ketenagalistrikan, instalasi gardu, serta LSP ini juga memberikan sertifikasi untuk pembangkit listrik bertenaga diesel. Energi terbarukan bagi sekolah menengah kejuruan direncanakan akan dikembangkan sebagai bagian dari manajemen kelistrikan. Namun masih terdapat tantangan yaitu belum tersedianya kurikulum karena materi tersebut 
masih tergolong sebagai kompetensi baru sehingga Lembaga Pelatihan Kerja (LPK) belum dapat melakukan uji kompetensi (Fitrina \& Kurniawan, 2020).

Perencanaan kapasitas pembangkit listrik dan target pemerintah untuk mencapai rasioelektrifikasi $100 \%$ pada tahun 2020 mulai didukung secara memadai. Dengan rencana agresif dalam mengembangkan energi terbarukan, Povinsi Maluku memerlukan model operasional untuk pengoperasian dan pemeliharaan jangka panjang atas pembangkit listrik yang telah terpasang. Selanjutnya, pentingnya dukungan dari sektor pendidikan untuk menyediakan tenaga kerja terampil yang dibutuhkan oleh industri daerah. Provinsi Maluku perlu memiliki jumlah lembaga pendidikan yang sepadan serta menyediakan program-program yang relevan dengan kebutuhan daerahnya. Hal ini juga harus diiringi dengan tenaga pengajar yang memiliki pengetahuan dan telah mendapatkan pelatihan yang tepat. Setelah itu, kurikulum perlu disesuaikan untuk memenuhi kebutuhan dan untuk mengembangkan kapasitas siswa di Provinsi Maluku.

Dengan tersedianya pusat pelatihan dan sertifikasi di Provinsi Maluku kami menyimpulkan fasilitas ini dapat menjadi wadah pengembangan masyarakat daerah dan sebagai bukti legalitas atas sumber daya manusia yang sudah berkualitas. Bantuan dari Selandia Baru yang juga ikut mendukung dalam pengembangan pengetahuan dan keterampilan masyarakat daerah tentunya juga dapat menjadikan sumber daya manusia di Provinsi Maluku menjadi masyarakat yang mandiri dan dapat lebih bertanggung jawab atas kebutuhan energi di daerahnya.

\section{Kebijakan Luar Negeri Provinsi Maluku dengan Selandia Baru}

Pada saat ini proses diplomasi telah mengalami perubahan dapat dilihat dengan terlibatnya aktor-aktor baru dalam hubungan internasional. Aktor sub-negara kini juga dapat memanfaatkan kapabilitas yang dimilikinya untuk mengeluarkan kebijakan luar negeri daerah, dengan ini Provinsi Maluku melalui koordinasi dengan pemerintah pusat dapat menjalin hubungan luar negeri dengan Selandia Baru dalam mendukung perkembangan energi untuk daerahnya. Pada tanggal 28 November 2018, Pemerintah Provinsi Maluku dan Duta Besar Selandia Baru untuk Indonesia meluncurkan program yang bernama "New Zealand Maluku Access to renewable Energy Support" (NZMATES) hubungan luar negeri ini ditandai dengan penandatangan Momerandum of Understanding (MoU) antara kedua belah pihak di Kantor Gubernur Maluku (Ririen, 2018). NZMATES didanai oleh Kementerian Luar Negeri dan Perdagangan Selandia Baru (New Zealand Aid) dan dalam implementasinya melibatkan Direktorat Jenderal Energi Baru Terbarukan dan Konservasi Energi (EBTKE), Kementrian ESDM; Perusahaan Listrik Negara; Infratec Ltd; dan Mercy Corps Indonesia. Program yang dilakukan akan mencakup bantuan untuk mengembangkan potensi energi terbarukan di Provinsi Maluku. NZMATES bersama Dinas ESDM dan PLN wilayah Maluku melakukan penilaian terhadap kebutuhan pelatihan Maluku pada akhir 2018 dan awal 2019 untuk memahami lokakarya seperti apa yang akan dilakukan dengan Dinas ESDM dan PLN wilayah Maluku. Pada bulan Mei 2019 NZMATES memberikan pelatihan pertama untuk Dinas ESDM dan PLN wilayah Maluku tentang praktik Pembangkit Listrik Tenaga Surya (PLTS) yang baik. Kemudian pada November 2019 dilanjutkan dengan pelatihan yang lebih mendalam tentang jaringan listrik tenaga surya. Pelatihan ini mencakup tentang desain, pengoperasian, perencanaan, dan pemeliharaan PLTS (NZMATES, 2020).

NZMATES juga menjalin hubungan dengan perguruan tinggi yang ada di Provinsi Maluku seperti Universitas Pattimura dan Politeknik Negeri Ambon. NZMATES dan Universitas Pattimura telah menandatangani MoU pada Mei 2019 
untuk perencanaan dalam pembentukan pelatihan pusat terkait PLTS di Ambon. Perguruan tinggi berikutnya adalah Politeknik Negeri Ambon yang juga ikut serta dalam mengembangkan pelatihan untuk pengoperasian PLTS dan telah menandatangani MoU pada September 2019 (NZMATES, 2020). Perguruan tinggi daerah dinilai dapat membantu NZMATES dalam mengidentifikasi bagaimana kondisi sumber daya, infrastruktur, dan tantangan yang ada di Provinsi Maluku, mengingat bahwa perguruan tinggi di Provinsi Maluku sudah memiliki fasilitas yang cukup memadai untuk mengidentifikasi bagaimana kondisi dan potensi yang ada di wilayah Maluku. Selain memberikan pembelajaran tentang energi terbarukan, NZMATES juga meningkatkan kapasitas para pengajar di perguruan tinggi dan memanfaatkan penggunaan fasilitas yang tersedia dengan lebih baik.

Seiring dengan kebutuhan dan tantangan dalam pembangunan energi di Provinsi Maluku, perguruan tinggi memiliki peran yang sangat penting dalam menyiapkan sumber daya manusia yang berpotensi tentunya untuk memenuhi kebutuhan dan menghadapi tantangan di daerahnya. Dengan ini, Universitas Pattimura dan Politeknik Negeri Ambon terus berupaya dalam meningkatkan kapabilitasnya untuk mendapat hasil yang optimal agar potensi sumber daya energi di Provinsi Maluku dapat dimanfaatkan dengan lebih baik. Pemerintah Provinsi Maluku juga terus berupaya dalam meningkatkan dan memanfaatkan potensi energi yang ada. Dengan melibatkan berbagai aktor di dalamnya, tentu dapat mempercepat proses pembangunan energi di Provinsi Maluku. Sumber daya manusia di Maluku diharapkan tidak lagi bergantung dengan sumber energi konvensional dan untuk kedepannya mereka dapat memanfaatkan sumber energi terbarukan yang tersebar di wilayah Maluku. Apabila potensi yang ada di Provinsi Maluku terus dikembangkan dan dimanfaatkan maka permasalahan yang dihadapi dapat terjawab.

Dengan adanya kebijakan luar negeri daerah ini, kami mengetahui bahwa ketersediaan kebijakan luar negeri antara Pemerintah Provinsi Maluku dengan Pemerintah Selandia Baru tentunya dapat mendukung proses pengembangan energi terbarukan di Provinsi Maluku. Kebijakan luar negeri daerah yang sudah ada tentunya juga dapat menjadi pedoman dan pembelajaran bagi berbagai lembaga daerah yang berkepentingan di wilayah Maluku guna mempercepat dan mengoptimalkan proses pengembangan energi terbarukan. Hal ini juga dapat mempermudah lembaga-lembaga daerah Maluku untuk lebih aktif menjalin hubungan luar negeri dengan berbagai aktor berkepentingan lainnya, baik dalam bentuk MoU maupun perjanjian lainya.

\section{Hubungan Luar Negeri NZMATES dengan Pemangku Kepentingan di Provinsi Maluku dalam Pengembangan Energi Terbarukan}

The New Zealand - Maluku Access to Renewable Energy Support (NZMATES) telah berdiri sejak April 2018. Program ini didukung oleh New Zealand Aid dan memiliki tujuan untuk meningkatkan akses terhadap energi dengan mempercepat pengembangan energi terbarukan. NZMATES menjalin kemitraan dengan Perusahaan Listrik Negara (PLN), Direktorat Jenderal Energi Baru Terbarukan dan Konservasi Energi (EBTKE) Kementerian Energi Sumber Daya dan Mineral (ESDM), dan Badan Perencanaan Pembangunan Daerah (Bappeda) Maluku. Hubungan kerjasama ini dilakukan untuk mempercepat pemanfaatan energi terbarukan melalui skema on-grid dan off-grid. NZMATES juga menyediakan layanan, dukungan, bantuan, serta bekerja sebagai penghubung dan mitra kerjasama pada seluruh tahapan dalam siklus proyek energi terbarukan daerah. 
Program ini juga membantu dalam mengembangkan alat bantu (toolkit), pedoman (guidelines), dan bahan-bahan (materials) untuk mendukung mitranya dan pihak lain yang memiliki ketertarikan untuk memperluas sektor energi terbarukan di Provinsi Maluku (NZMATES, 2018).

NZMATES juga memberi dukungan serta bekerjasama dengan berbagai pemangku kepentingan di sektor energi terbarukan di wilayah Provinsi Maluku seperti pemerintah provinsi, pemerintah kabupaten, serta lembaga pendidikan daerah Maluku. NZMATES berusaha untuk memperkuat hubungan antara berbagai lembaga dengan aktor yang bekerja di sektor energi terbarukan, serta hubungan dengan para ahli dari Selandia Baru atau negara lainnya, memastikan ketersediaan informasi dan akses ke sumber daya energi, membentuk kemitraan yang memungkinkan para aktor baru untuk ikut memperluas dan mengembangkan kapasitasnya di sektor energi terbarukan. NZMATES menyediakan pelatihan pengembangan kapasitas kepada Pemerintah Provinsi Maluku dan PLN guna mengatasi masalah terkait sistem tenaga surya dan minihidro. Pelatihan ini terfokus kepada teknologi pembangkit listrik surya dan penyimpanan mini-grid, diberikan kepada PLN dan Dinas ESDM wilayah Maluku. NZMATES juga memberikan sesi pendampingan kepada tenaga kerja PLN Maluku dan Maluku Utara yang berfokus terhadap pemanfaatan perangkat lunak, desain, dan perencanaan untuk pembangunan energi terbarukan. NZMATES melakukan penilaian atas aset yang ada untuk mengidentifikasi perencanaan kedepan, mengumpulkan pembelajaran yang didapat, dan mencari langkah berkelanjutan untuk proyek-proyek berikutnya. Sudah hampir 20 penilaian telah dilakukan NZMATES pada pembangkit listrik berbasis energi terbarukan. Dari kunjungan yang telah dilakukan, ditemukan 9 dari 10 PLTS yang dimiliki PLN telah mencapai akhir dari masa penggunaanya, bersama dengan 25 proyek yang didukung oleh EBTKE yang tidak lagi berfungsi termasuk yang disumbangkan kepada penduduk setempat untuk dioperasikan. Beberapa aspek menjadi hambatan dalam proses pengembangan energi terbarukan daerah yaitu pada aspek teknis, implementasi, desain, pengoperasian, model, manajemen, serta aspek-aspek lain yang berdampak pada proses pengembangan pembangkit listrik dan menurunkan durasi masa penggunaan PLTS (NZMATES , 2020).

Berdasarkan pengalaman proyek-proyek yang telah dilakukan dapat menunjukan bahwa akan selalu ada cara yang lebih baik dalam perencanaan proyek selanjutnya dan meningkatkan keberlanjutannya. Tentunya dengan rencana yang lebih optimal, implementasi yang lebih baik, serta model pengoperasian untuk jangka panjang. Seluruh informasi terkait energi digunakan NZMATES sebagai pembelajaran untuk mendukung mitranya dalam mengembangkan RUED agar dapat menyusun rencana implementasi energi terbarukan di masa mendatang dengan lebih baik. Selain itu, NZMATES juga memberikan pelatihan kepada tenaga kerja Dinas Energi dan Sumber Daya Mineral (ESDM) Maluku tentang perencanaan dan pendekatan kolaboratif untuk proses perencanaan antara Dinas ESDM dengan PLN, Bappeda, dan pemangku kepentingan lainnya seperti perguruan tinggi di Provinsi Maluku. Ini merupakan pekerjaan yang sangat berharga karena sangat membantu pemerintah dalam memastikan bahwa sebelum berjalannya proses pengembangan pembangkit energi terbarukan dimulai, harus ada langkah yang jelas untuk kedepannya baik dari segi investasi biaya modal hingga dari segi pengoperasian serta pemeliharaan untuk jangka panjang. Berbagai program pelatihan dan peningkatan kapasitas energi terbarukan telah diadakan untuk tenaga kerja di kantor PLN dan Dinas ESDM wilayah Maluku, terutama 
mengembangkan pembangkit listrik tenaga surya. Pelatihan ini disampaikan oleh seorang spesialis dari Infratec Ltd yaitu Dr. Andrew Crossland. Selama masa pelatihan para peserta diharapkan dapat memahami aspek-aspek utama dari desain dan pengoperasian teknologi surya sehingga dapat meningkatkan keberlanjutannya dalam jangka panjang.

Pada awalnya NZMATES bertujuan untuk meningkatkan rasio elektrifikasi di Pulau Seram dan memberikan peluang bagi pengembangan pembangkit energi bertenaga surya karena beberapa daerah di pulau ini masih memiliki tingkat rasio elektrifikasi yang rendah. Pulau Seram masih diduduki dengan sejumlah besar orang yang belum memiliki akses kelistrikan. Walaupun jika dibandingkan dengan Kepulauan Tanimbar dan Aru, Kepulauan Seram secara keseluruhan masih memiliki daerah-daerah dengan akses listrik yang lebih baik (NZMATES, 2018). Dengan ini NZMATES bersama mitra kerjanya menjadikan pulau-pulau di hampir seluruh Kabupaten di Provinsi Maluku menjadi area kerjanya dalam mengembangkan energi terbarukan. Hingga saat ini NZMATES terus berupaya dalam mencari mitra untuk terus berkolaborasi, terutama dalam mengembangkan sistem pembangkit listrik tenaga surya. Selain menyediakan akses listrik untuk daerah, NZMATES juga berkontribusi untuk memberdayakan masyarakat daerah dengan melibatkan mereka dalam pengoperasian dan pemeliharaan sistem ketenagalistrikan.

NZMATES juga membantu mengidentifikasi kebutuhan Provinsi Maluku akan pengetahuan dan keterampilan agar lebih baik untuk mendukung proses pengembangan energi terbarukan Provinsi Maluku meningkat pesat. Demi menanggapi hal ini NZMATES juga mengembangkan sebuah program yang menawarkan peluang untuk pelatihan teknis, pendampingan, dan pertukaran pengetahuan untuk lembaga pendidikan di wilayah Maluku. Program tersebut bertujuan untuk meningkatkan kapasitas tenaga pengajar tentang pembangkit listrik berbasis energi terbarukan melalui pengembangan pengetahuan dan keterampilan. NZMATES memfasilitasi tenaga pengajar untuk berpartisipasi dalam kursus pelatihan tentang PLTS yang didukung oleh Deutsche Gesellschaft für Internationale (GIZ) lembaga kerjasama Indonesia-German. Tenaga pengajar yang mengikuti pelatihan ini adalah dosen dari Universitas Pattimura dan Politeknik Negeri Ambon. Setelah menyelesaikan pelatihan, tenaga pengajar akan mengajar dan mengembangkan kursus tentang PLTS di masing-masing lembaganya.

Dengan menargetkan peningkatan kapasitas institusi pendidikan dan memastikan siswa dapat menerima dukungan yang baik dalam pengembangan pengetahuan dan keterampilan tentang energi terbarukan. NZMATES menjalin kerjasama dengan Universitas Pattimura dan Politeknik Negeri Ambon untuk menyediakan peningkatan kapasitas bagi para tenaga pengajar, menambah fasilitas laboratorium, dan fasilitas-fasilitas yang sekiranya dapat mendukung penelitian dan pembelajaran. Upaya ini dilakukan untuk memperkenalkan kepada para siswa akan konsep dasar energi terbarukan sehingga bagi para siswa yang memiliki keterkatikan dapat mengikuti penelitian atau mengambil pendidikan lebih lanjut di bidang energi terbarukan. Para siswa juga dapat memanfaatkan fasilitas yang sudah disediakan dengan lebih baik terutama dalam mengembangkan pengetahuan dan keterampilan mereka terkait potensi energi terbarukan yang terdapat di wilayah Maluku. Komitmen Universitas Pattimura dan Politeknik Negeri Ambon untuk fokus terhadap pelatihan ini, tentunya agar para siswanya dapat terus mengembangkan pengetahuan dan keterampilannya sehingga dapat mengatasi permasalahan yang ada di daerah Maluku. Dukungan NZMATES untuk lembaga pendidikan seperti Universitas Pattimura dan Politeknik Negeri Ambon, memungkinkan perguruan tinggi tersebut untuk terus meningkatkan 
pengetahuan dan keterampilan para siswanya. Sehingga di masa mendatang para siswa lulusan dari perguruan tinggi tersebut dapat bermanfaat bagi daerahnya dan berpartisipasi dalam proses pengembangan energi terbarukan di wilayah Maluku. Dengan demikian, lembaga pendidikan di Provinsi Maluku diharapkan dapat terus mempertahankan kapasitas mereka secara mandiri dan dapat terus ikut memberi dukungan dalam memenuhi kebutuhan daerahnya.

Pada hubungan luar negeri Provinsi Maluku dengan Selandia Baru, kami menafsirkan bahwa terdapat berbagai aspek yang dapat mendukung pengembangan energi terbarukan di Provinsi Maluku. Di awali dengan pembentukan berbagai kebijakan daerah terkait energi seperti target bauran energi tahunan, lalu penyediaan fasilitas seperti BLK dan LSP, program pelatihan untuk para tenaga kerja dari lembaga terkait, hingga pengembangan pengetahuan dan keterampilan untuk para tenaga pengajar beserta siswanya. Semua ini dilakukan tentunya agar seluruh masyarakat di Provinsi Maluku dapat mengejar target bauran energi yang telah ditentukan sehingga masyarakat Maluku dapat lebih cepat memenuhi kebutuhan energinya dan mencapai kesejahteraan.

Pemerintah Provinsi Maluku menyadari akan kebutuhan daerahnya atas kelistrikan yang begitu besar. Dengan meningkatkan kebutuhan listrik tentunya dapat juga meningkatkan perekonomian masyarakat, kualitas layanan pendidikan, hingga kesehatan serta ketahanan energi di wilayah Maluku itu sendiri. Keterbatasan akses listrik yang terjadi disebabkan karena selama ini Maluku masih terus bergantung pada bahan bakar fosil sebagai sumber pembangkit listrik di daerahnya. Maka dari itu Pemerintah Provinsi Maluku menjalin hubungan kerjasama dengan Selandia Baru dalam mengembangkan potensi sumber daya energi terbarukan di daerahnya.

Berdasarkan MoU antara Pemerintah Provinsi Maluku dengan Pemerintah Selandia Baru. Selandia Baru menyediakan bantuan dana dengan jumlah sebesar New Zealand Dollar (NZD) 10 juta sekitar Rp. 985 miliar untuk investasi dalam mengembangkan energi terbarukan di wilayah Maluku. Selain itu Selandia Baru juga memberi bantuan tenaga ahli yang akan mengedukasi masyarakat Provinsi Maluku terkait isu-isu energi (NZMATES, 2018). Ini sesuai dengan program New Zealand Aid untuk Indonesia, yang dimana Selandia Baru memang memiliki fokus pada peningkatan pasokan energi, peningkatan hasil pertanian, penyediaan pendidikan tinggi, dan penanggulangan bencana. Selain itu, program donor ini juga memiliki fokus khusus di provinsi-provinsi paling tertinggal di wilayah Indonesia Timur (New Zealand Ministry of Foreign Affairs and Trade, 2020).

\section{Kesimpulan}

Hubungan luar negeri antara Pemerintah Provinsi Maluku dengan Pemerintah Selandia Baru dapat terjalin melalui upaya paradiplomasi Pemerintah Provinsi Maluku mengenai potensi pengembangan energi terbarukan. Program NZMATES telah membantu Maluku dalam memenuhi kebutuhan terhadap akses energi daerah. Walaupun sudah hampir mencapai targetnya, saat ini masih terdapat beberapa hambatan dan kekurangan di beberapa daerah. Pembangunan dan penyediaan pasokan listrik masih perlu dipelajari lebih dalam. NZMATES melihat energi terbarukan di Provinsi Maluku memiliki potensi untuk mengatasi permasalahan akses energi listrik di daerah Maluku. Energi terbarukan juga dinilai memiliki banyak manfaat bagi Maluku, selain kontribusinya dalam upaya mitigasi perubahan iklim, energi terbarukan juga dapat memperkuat kondisi ekonomi daerah dengan memberdayakan masyarakat daerah.

Proses pengembangan energi terbarukan ini diiringi dengan kebijakan pemerintah Indonesia seperti RUEN, RUKN dan RUPTL yang menjadi landasan 
untuk memasukan energi terbarukan dalam perencanaan pembangunan daerah. Perencanaan ini tentunya menciptakan model bisnis baru yang dapat terus ditingkatkan implementasinya di masa mendatang. Kebijakan-kebijakan tersebut juga mendukung proses pembangunan pembangkit listrik yang berkelanjutan. Keterlibatan pemerintah pusat dan pemerintah daerah melalui kebijakan terkait energi terbarukan dapat memastikan bahwa energi terbarukan perlu diutamakan dalam pengembangan pembangkit listrik, dengan ini daya tarik investasi pada sektor energi terbarukan dapat meningkat. Selain masalah akses terhadap listrik, NZMATES juga ikut berupaya dalam mengatasi permasalahan pengetahuan dan keterampilan di daerah-daerah Maluku, terutama terkait pemanfaatan sumber daya energi terbarukan sebagai pembangkit listrik.

Setiap lembaga daerah Maluku diharapkan untuk dapat terus menjalin hubungan luar negeri dengan berbagai aktor-aktor berkepentingan lain sehingga dapat terus menciptakan lingkungan yang mempermudah mereka untuk mengembangkan energi terbarukan, mengingat banyaknya tantangan dan hambatan yang ada pada proses pengembangan energi terbarukan di wilayah Maluku. Selain itu, Indonesia masih belum memiliki undang-undang yang dapat menjadi payung bagi semua regulasi terkait energi terbarukan. Hal ini mengakibatkan ketidakpastian hukum dan politik sehingga dapat menghambat proses pengembangan energi terbarukan di Indonesia itu sendiri. Maka dari itu diperlukannya undang-undang tentang energi terbarukan yang sekiranya dapat menjadi sebuah payung bagi semua regulasi terkait energi terbarukan sehingga dapat memastikan peran energi terbarukan secara lebih jelas.

Pemerintah Provinsi Maluku sebagai aktor subnegara dapat memenuhi kebutuhan dan mengatasi permasalahan daerahnya dengan menjalin hubungan luar negeri dengan berbagai aktor berkepentingan lainya. Melalui kerjasama dengan berbagai pemangku kepentingan mulai dari pemerintah pusat, pemerintah daerah, lembaga pendidikan, perusahaan swasta, hingga masyarakat daerah itu sendiri. Terbentuknya NZMATES telah membantu Provinsi Maluku dalam menciptakan lingkungan yang memungkinkan untuk menghasilkan tenaga kerja yang sesuai dengan potensi dan kebutuhan daerahnya.

Berdasarkan hasil penelitian ini, tulisan ini menemukan bahwa keterlibatan aktor subnegara di Indonesia mampu memberi kontribusi bagi upaya pembangunan, khususnya dalam konteks penelitian ini adalah pengembangan sumber energi terbarukan. Pada upaya pengembangan sumber energi terbarukan ini, Provinsi Maluku sebagai aktor subnegara di Indonesia memiliki kapasitas di dalam hubungan internasional, yaitu aktif terlibat menjalin hubungan luar negeri daerah dan melakukan paradiplomasi untuk membawa peluang-peluang sumber-sumber luar negeri ke Provinsi Maluku bagi kepentingan pembangunan daerahnya. Dengan demikian, potensi dan peluang aktor subnegara di Indonesia dapat dikembangkan melalui penguatan kapasitas daerah dalam melakukan hubungan luar negeri daerah dan kiprahnya dalam berparadiplomasi.

\section{Daftar Pustaka}

Aftab, S. (2014). Pakistan's Energy Crisis: Causes, Consequences and Possible Remedies. Noref Expert Analysis, pp. 1-4.

Amin. (2020). Dubes Selandia Baru: Energi Terbarukan Dibutuhkan di Maluku [Online]. 27 Februari. Tersedia di: <https://www.malukuterkini. com/2020/02/27/dubes-selandia-baru-energi-terbarukan-dibutuhkan-dimaluku/> [diakses 15 April 2020]. 
Anchank. (2020). Sejumlah Desa di Maluku Belum Teraliri Listrik PLN Didesak Bangun PLTD [Online]. 6 Juli. Tersedia di: <https://faktapers.id/2020/07/sejumlah-desa-di-maluku-belumteraliri-listrik-pln-didesak-bangun-pltd/> [diakses 15 April 2020].

Arumingtyas, L. (2019). Pengembangan Energi Terbarukan Perlu Jadi Prioritas [Online]. 30 April. Tersedia di: <https://www.mongabay.co.id/2019/04/30/ pengembangan-energi-terbarukan-perlu-jadi-prioritas/> [diakses 15 April 2020].

Barnett, M. (1990). High Politics Is Low Politics: The Domestic and Systemic Sources of Israeli Security Policy, 1967-1977. World Politics, 42 (4), pp. 529-562.

Cahyanto, A. (2014). Energi Terbarukan Pengganti Minyak Bumi [Online]. 21 Juni. Tersedia di: <https://www.medanbisnisdaily.com/news/ $\mathrm{read} / 2014 / 06 / 21 / 101893 /$ energi-terbarukan-pengganti-minyak-bumi/> [diakses 15 April 2020].

Coyle, E.D., \& Simmons, R.A. (2014). Understanding the Global Energy Crisis. Lafayette: Purdue University Press.

Dewan Energi Nasional. (2014). Kebijakan Energi Nasional (KEN) Road Map Kebijakan Ketahanan dan Kemandirian Energi [Online]. 26 Juni. Tersedia di: <https://den.go.id/index.php/dinamispage/index/471-. html\#: :text=Kebijakan\%20Energi\%20Nasional\%20(\%20KEN\%20)\%20 Road\%20Map\%20Kebijakan\%20Ketahanan\%20dan\%20Kemandirian\%20 Energi\&text=Seperti $\% 20$ tertuang $\% 20$ dala m $\% 20$ ketentuan $\% 20$ umum,energi\%20guna\%20mendukung\%20pe> [diakses 15 April 2020].

Dewan Energi Nasional. (2020). Perkembangan Bauran Energi Primer Nasional Tahun 2015-2019 [Online]. Tersedia di: <https://www.den.go.id/index.php/ dinamispage/index/869-perkembangan-bauran-energi-primer-nasionaltahun-20152019.html> [diakses 15 April 2020].

Ditjen EBTKE. (2020). Rencana Strategis 2020-2024. Jakarta: Direktorat Jenderal Energi Baru Terbarukan dan Konservasi Energi Kementerian Energi dan Sumber Daya Mineral .

Fitra, H.A., \& Asirin. (2018). Ketahanan Masyarakat terhadap Ancaman Krisis Energi Listrik di Kabupaten Lampung Selatan, Provinsi Lampung. Jurnal Wilayah dan Lingkungan, 6 (1), pp. 59-71.

Fitrina, E., \& Kurniawan, A. (2020). Supporting the Advanced Knowledge and Skills for Sustainable Growth Project: Study on Skills for the Electricity Sector Volume 2: Case Studies South Sulawesi, Maluku and West Nusa Tenggara (Bilingual). Jakarta: Asian Development Bank.

Harakan, A. (2018). Paradiplomasi dalam Percepatan Pembangunan Infrastruktur Fisik dan Sosial di Kabupaten Bantaeng. Jurnal PIR: Power in International Relations, 3 (1), pp. 3-12.

Hariyanti, D. (2016). Energi Baru Terbarukan PT PJB Manfaatkan Sinar Surya Gelombang Laut Angin dan Rumput Laut [Online]. 17 Maret. Tersedia di: <https://ekonomi.bisnis.com/read/20160317/44/528969/energibaru-terbarukan-pt-pjb-manfaatkan-sinar-surya-gelombang-laut-angin-danrumput-laut> [diakses 15 April 2020].

Heyko, E., Hasid, Z., \& Priyagus. (2016). Strategi Pemanfaatan Energi Terbarukan dalam Rangka Kemandirian Daerah Provinsi Kalimantan Timur. Journals of Economics and Business Mulawarman, 12 (1), pp. 2-21.

Kementerian Energi dan Sumber Daya Mineral. (2017). Kajian Penyediaan Dan Pemanfaatan Migas, Batubara, EBT Dan Listrik, Jakarta: Pusat Data dan Teknologi Informasi Energi dan Sumber Daya Mineral. 
Kementerian ESDM. (2016). Rencana Umum Ketenagalistrikan Nasional [Online]. 22 Juli. Tersedia di: <https://gatrik.esdm.go.id/assets/uploads/download_ index/files/62781-rencana-umum-ketenagalistrikan-nasional-rukn-dirpro. pdf $>$ [diakses 15 April 2020].

Kementerian Luar Negeri RI. (2018). Selandia Baru [Online]. Tersedia di: <https://kemlu.go.id/wellington/id/read/selandia-baru/69/ information-sheet $>$ [diakses 15 April 2020].

Keohane, R., \& Nye, J. (1974). Transgovernmental Relations and International Organizations. World Politics, 27 (1), pp. 39-62.

Kholiq, I. (2015). Pemanfaatan Energi Alternatif sebagai Energi. Jurnal IPTEK, 19 (2), pp. 76-90.

Kusumawanti, R. (2020). Selandia Baru Perkuat Dukungan untuk Energi Bersih di Indonesia [Online]. 7 September. Tersedia di: <https://www.portonews. com/2020/laporan-utama/selandia-baru-perkuat-dukungan-untuk-energibersih-di-indonesia/> [diakses 15 April 2020].

Kuznetsov, A. (2015). Theory and Practice of Paradiplomacy: Subnational Governments in International Affairs. London: Routledge.

Lubis, A. (2007). Energi Terbarukan dalam Pembangunan. Jurnal Teknologi Lingkungan - Jurnal BPPT, 8 (2), pp. 156-162.

Manieniyan, V., Thambidurai, M., \& Selvakumar, R. (2009). Study on Energy Crisis and The Future of Fossil. Annamalai University.

Mayaut, P.F. (2019). Rasio Elektrifikasi Maluku Capai 82,66 Persen [Online]. 26 Oktober. Tersedia di: <https://ambon.antaranews.com/berita/69404/rasioelektrifikasi-maluku-capai-8266-persen> [diakses 15 April 2020].

New Zealand Ministry of Foreign Affairs and Trade. (2020). Aid Partnership With Indonesia [Online]. Tersedia di: <https://www.mfat.govt.nz/en/countriesand-regions/south-east-asia/indonesia/\#aid> [diakses 15 April 2020].

NZMATES. (2020). Annual Report April 2019-2020. Maluku: NZMATES .

NZMATES. (2018). What is NZMATES [Online]. Tersedia di: <https://www. nzmates.org/about/what-nzmates> [diakses 15 April 2020].

NZMATES. (2019). About Maluku and New Zealand [Online] Tersedia di: <https://www.nzmates.org/about/about-new-zealand-maluku> [diakses 15 April 2020].

NZMATES. (2020). NZMATES Capacity Building [Online]. Tersedia di: <https://nzmates.org/activity/capacity-building> [diakses 15 April 2020].

Pemerintah Indonesia. (2014). Peraturan Pemerintah Republik Indonesia Nomor 79 Tahun 2014 tentang Kebijakan Energi Nasional.

Pemerintah Indonesia. (2014). Peraturan Pemerintah tentang Perubahan atas Peraturan Pemerintah Nomor 14 Tahun 2012 tentang Kegiatan Usaha Penyediaan Tenaga.

Pemerintah Indonesia. (2017). Peraturan Presiden Nomor 22 Tahun 2017 tentang Rencana Umum Energi Nasional.

Pluijm, R.v.d. \& Melissen, J. (2007). City Diplomacy: The Expanding Role of Cities in International Politics. Den Haag: Clingendael Institute.

Puspitarini, H.D. (2015). Analisis Kelangkaan Energi Terbarukan di Eropa Berdasarkan Pendekatan Ambang Batas. Tesis Magister. Institut Teknologi Sepuluh Nopember. 
Rei, F.C.F. \& Cunha, K.B. (2011). The Environmental Paradiplomacy in a New International Governance. Makalah disampaikan pada $1^{\text {st }}$ World Sustainability Forum.

Ririen, K. (2018). Selandia Baru Siapkan NZD 10 Juta Untuk Program NZMATES di Maluku [Online]. 15 November. Tersedia di: <https://www.antaranews. com/berita/2524141/ri-selandia-baru-bangun-kemitraan-di-bidang-transisienergi> [diakses 15 April 2020].

Schwanitz, V.J., Wierling, A., \& Sha, P. (2017). Assessing the Impact of Renewable Energy on Regional Sustainability: A Comparative Study of Sogn og Fjordane (Norway) and Okinawa (Japan). Sustainability, 9 (11), pp. 2-29.

Sekretariat Jenderal Ketenagalistrikan. (2018). Statistik Ketenaga Listrikan Tahun 2018. Jakarta: Kementerian Energi Sumber Daya dan Mineral.

Sergunin, A., \& Joenniemi, P. (2014). Paradiplomacy as a CapacityBuilding Strategy: the Case of Russia's Northwestern Subnational Actors. Problems of Post-Communism, 61 (6), pp. 18-31.

Slaughter, A.M. (1997). The Real New World Order. Foreign Affairs, 76 (5), pp. 183197.

Tavarez, R. (2016). Paradiplomacy: Cities and States as Global Players. New York: Oxford University Press.

Teske, S., Obusan, A., Buakamsri, T., \& Sawyer, S. (2013). Energy [R]Evolution: A Sustainable ASEAN Energy Outlook [Online]. 24 September. Tersedia di: $\quad<$ https://www.greenpeace.org/philippines/publication/2489/energyrevolution-a-sustainable-asean-energy-outlook/> [diakses 15 April 2020].

Thontowi, J. (2009). Kewenangan Daerah Dalam Melaksanakan Hubungan Luar Negeri: Studi Kasus di Propinsi Jawa Barat dan DIY. Jurnal Hukum, 16 (2), pp. 149-168.

Whytock, C. (2005). A Rational Design Theory of Transgovernmentalism: The Case of E.U-U.S Merger Review Cooperation. Boston University International Law Journal, 23 (1), pp. 127-130. 